\title{
AZ ATOMI MAGASFELHARMONIKUS-KELTÉS POLARIZÁCIÓFÜGGÉSE DISZKRÉT BÁZIS ESETÉN
}

\author{
Kasza József ${ }^{1,3}$, Dombi Péter ${ }^{1,2}$, Földi Péter ${ }^{1,3}$ \\ ${ }^{1}$ ELI-ALPS, ELI-HU Non-Profit Kft., Wolfgang Sandner utca 3, 6728 Szeged \\ ${ }^{2}$ Wigner Fizikai Kutatóközpont, Konkoly-Thege M. út 29-33, 1121 Budapest \\ ${ }^{3}$ Szegedi Tudományegyetem, Elméleti Fizikai Tanszék, Tisza L. krt. 84-86, 6720 Szeged
}

DOI: https://doi.org/10.14232/kvantumelektronika.9.16

\section{Bevezetés}

Atomi rendszerek esetén a magasrendű felharmonikusok keltése jól ismert, mind kísérletileg [1,2], mind pedig elméleti úton sokat tanulmányozott jelenség [3,4]. A legelterjedtebb elméleti magyarázat ráadásul jól interpretálható, szemléletes képet szolgáltat: Az erős lézertér kiszakítja az atomi elektront a mag vonzásából, felgyorsítja azt, de a következő optikai félciklusban az elektron visszatér, és a mozgása során nyert energiát részben magasfelharmonikusok formájában bocsájtja ki. Ehhez természetes az szükséges, hogy az elektron valóban „visszatérjen”, azaz a második optikai félciklusban hullámfüggvényének jelentős része fedjen át a kiinduló atommal. Ez lineárisan polarizált gerjesztő tér esetén meg is történik, ugyanakkor könnyen látható módon a cirkulárisan poláros tér olyan klasszikus trajektóriákat hoz létre, amelyek nem térnek vissza a kiindulópontra. Ezt a valós térben végzett kvantummechanikai számítások is igazolják. Természtesen a magasfelharmonikuskeltés polarizációfüggése kísérletileg is ismert, sőt technológiai szempontból is alkalmazott tény (polarizációs kapuzás [5]). Érdekes módon több atomot tartalmazó klaszterek esetén is kimutatható a polarizációfüggés [6,7].

Felmerül a kérdés, hogy ha nem a valós térben, hanem egy diszkrét bázison írjuk le a jelenséget, hogyan interpretálható ez a tapasztalat. Hidrogén atomra gondolva, ez a bázis természetesen nem lehet a kötött állapotok szokásosan $n, l, m$ kvantumszámokkal indexelt rendszere, hiszen azok nem tartalmazzák a pozitív energiás, szórt állapotokat, amelyek szerepe a fentiek alapján alapvető a felharmonikusok létrejötte szempontjából. Ezzel szemben az ún. Sturm-állapotok [8] olyan bázist alkotnak, amelyek diszkrét rendszert alkotnak, ugyanakkor tartalmazzák a szórt állapotokat is. A továbbiakban ezt a bázist alkalmazva mutatunk rá, hogy az átmeneti dipólmomentumok szimmetria tulajdonságai hogyan vezetnek a magasfelharmonikus-keltés polarizációfüggéséhez. Eredményeink egyrészt a folyamat egy alternatív interpretációját adják, másrészt rávilágítanak arra, hogy az átmeneti dipólmomentum mátrixelemek fázisa ebben az esetben is jelentős szerepet játszik. (Egyetlen átmenet esetén ez a fázis nem játszik szerepet, de több átmenetet figyelembe véve a relatív fázisok természetesen lényegesek. Érdekes módon pl. szilárdtestek esetén erre csak az utóbbi években mutattak rá [9]. )

\section{Modell}

Az atomi méreteket figyelembe véve a dipólközelítés nagyon pontos leírást ad már optikai tartományba eső gerjesztés esetén is. Hosszmértéket használva írhatjuk, hogy

$$
H=H_{\boldsymbol{a t}}-\boldsymbol{E}(t) \boldsymbol{D},
$$

ahol $H_{\boldsymbol{a}}$ a szabad atom Hamilton-operátora, $\boldsymbol{E}(t)$ a lézertér elektromos tere, míg $\boldsymbol{D}$ az atomi dipólmomentum operátora. A továbbiakban először az ezekhez az operátorokhoz tartozó mátrixokat 
határozzuk meg a Sturm-bázisban. Ennek a bázisnak ez elemei koordinátareprezentációban csupán a radiális részben különböznek a szokásos kötött hidrogén állapotoktól. Ez azt is jelenti, hogy a kontinuum reprezentációjóban most gömbfüggvények írják le az állapotok szögfüggését, ilyen értelemben "strukturált" kontinuumról beszélhetünk. A szórt állapotok reprezentálhatóságának az ára az, hogy $H_{\boldsymbol{a t}}$ nem diagonális ebben a bázisban. Mivel a kiválasztási szabályokat a hullámfüggvények szögfüggő része határozza meg, azok ugyanazok, mint a kötött állapotok esetében. Az egyszerüség kedvéért a bejövő elektromágneses impulzust az x-y síkban polarizáltnak tekintjük, így most csak $D_{x}=e X$ és $D_{y}=e Y$ játszik szerepet, ami a $\Delta l= \pm 1, \Delta m= \pm 1$ szabályokat jelenti.

A numerikus megoldhatóságot figyelembe véve ennek a bázisnak egy véges részét használjuk, ami praktikus szempontból nem jelent megszorítást, mivel akkora bázist fogunk használni, amely esetén - adott intenzitású külső tér esetén - további bázisállapotok figyelembe vétele már nem befolyásolja az eredményt.

A továbbiakban két típusú, cirkulárisan és (az x irányban) lineárisan polarizált elektromos teret fogunk tanulmányozni. Ekkor

$$
\boldsymbol{D} \boldsymbol{E}_{\text {lin }}=f(t) \cos (\omega t)\left(D_{x} E_{0}\right), \quad \boldsymbol{D} \boldsymbol{E}_{\text {cirk }}=f(t) E_{0}\left(D_{x} \cos (\omega t)+D_{y} \sin (\omega t)\right)
$$

ahol az $\mathrm{f}(\mathrm{t})$ burkolófüggvény lassan változik a periódusidőhöz képest. A továbbiakban $f(t)=$ $\cos ^{2}(t / \tau)$, és $\tau$-t úgy választjuk meg, hogy az intenzitás maximumát tekintve viszonylag hosszú, legalább 10 ciklusú impulzusokat vizsgálhassunk.

\section{Eredmények}

A felharmonikusok frekvencia szerinti eloszlását a D operátor x és y komponensének időfüggő várható értékéhez tartozó intenzitásspektrumok összege adja. A két típusú gerjesztés esetén a számításainkból adódó spektrumok láthatók az alábbi két ábrán, ahol a függőleges tengelyen önkényes egységeket alkalmaztunk.

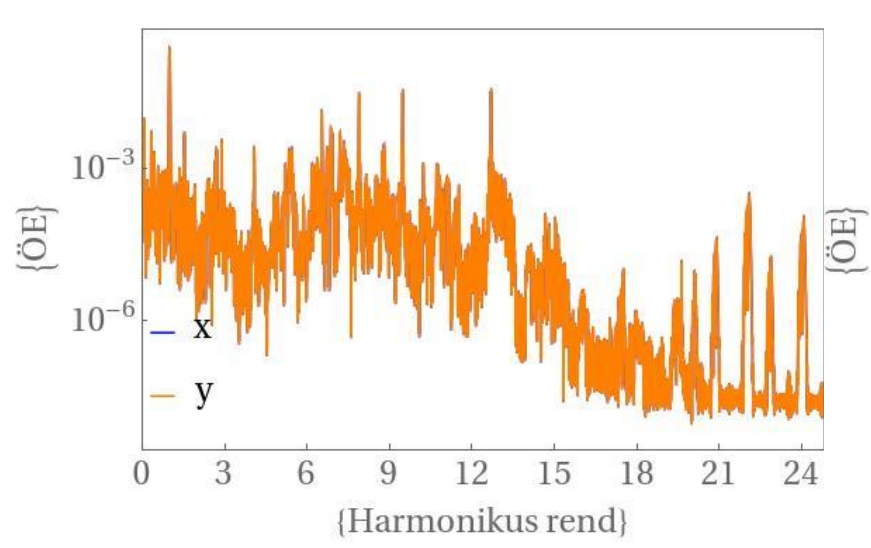

1/a Ábra: Lineárisan poláros fénnyel gerjesztett atom intenzitásspektruma (A számításnál az x és y tengellyel 45 fokos szöget bezáró polarizációt használtunk)

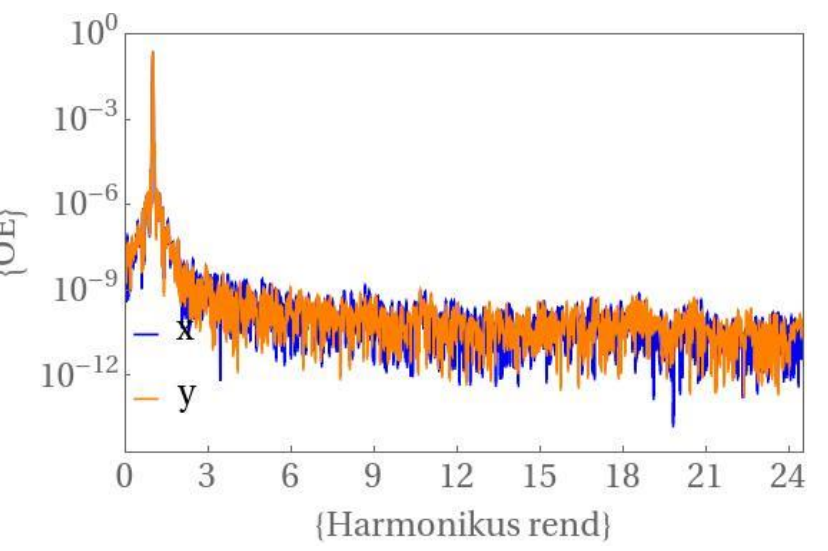

1/b Ábra: Cirkulárisan poláros fénnyel gerjesztett atom válaszjele.(Kékkel a dipól operátor $\mathrm{x}$ komponensének várható értékéhez tartozó intenzitásspektrum) 
Amint láthatjuk, ezek az eredmények teljesen egybecsengenek azzal, amit mind kísérleti úton, mind pedig a mostani modelltől eltérő elméleti számítások alkalmazásával kaphatunk.

Számításaink azt mutatják, hogy a felharmonikusok hiánya nagyon erősen függ attól, hogy az átmeneti dipólmomentum mátrixelemek (azaz $\boldsymbol{D}$ mátrixelemei) fázisai pontosan mekkorák is. Ha ezeket a fázisviszonyokat elhanyagoljuk (pl.azzal, hogy minden mátrixelemnek csak az abszolút értékét tekintjük), akkor cirkulárisan poláros gerjesztés esetén is kapunk felharmonikusokat.

Mindez azt sugallja, hogy a magasfelharmonikus-keltés polarizációfüggése kvantummechanikai értelemben vett interferenciajelenségeken múlik. A pontos részletek azt mutatják, hogy ebben az esetben ez nem azt jelenti, hogy maguk az időfüggő Schrödinger egyenlet megoldásai is csak alacsony frekvenciás $(\sim \omega)$ komponenseket tartalmaznak. Ez abban a kontextusban érdekes, hogy a probléma sok hasonlóságot mutat a jól ismert kétnívós rendszerek esetével. Ilyenkor persze nincs értelme a kontinuumról beszélni, de az analógia szembeötlö. Kétnívósnak tekeinthető rendszerek cirkulárisan poláros fénnyel történő gerjesztésekor az úgynevezett forgóhullámú közelítés (azaz az átmenetei és a gerjesztő frekvencia összegéhez tartozó oszcillációk elhanyagolása) egzakt, azaz valójában nem is közelítés [10]. Ez azzal is jár, hogy folytonos, monokromatikus gerjesztés esetén a dinamika analitikusan megoldható, és a felharmonikusok teljesen hiányoznak. Esetünkben a probléma összetettebb, de a forgóhullámú közelítésnek megfelelö

$$
\boldsymbol{D} \boldsymbol{E}_{\text {cirk }}=f(t) E_{0}\left(D^{+} \exp (-i \omega t)+D^{-} \exp (i \omega t)\right)
$$

összefüggés - amely a dipólmomentum operátor komponenseinek szimmetria tulajdonságaiból fakad - most is fennáll. Itt $D^{ \pm}=D_{x} \pm i D_{y}$, és ezekre az operátorokra a $\Delta m=1$, illetve $\Delta m=-1$ kiválasztási szabályok vonatkoznak. Ez azt jelenti, hogy a gerjesztésben megjelenő pozitív (negatív) frekvenciás részek pusztán növelhetik (csökkenthetik) az $m$ kvantumszámot. Ez azonban esetünkben nem ad könnyen felírható megoldást, és a numerikus módszerek azt mutatják, hogy a rendszer állapotát megadó időfüggő szuperpozícióban megjelennek a felharmonikusok. Emellett az is igaz, hogy nehéz rámutatni a dinamikának olyan kvalitatív részletére, amely az (1) egyenletben részletezett két esetben különbözik. Másszóval, a cirkulárisan poláros gerjesztés esetén hiányzó felharmonikusok nem magától értetődő destruktív interferencia következményei.

Ezzel szemben a dipólmomentum operátor komponensek várható értékének időfüggése már nem tartalmaz felharmonikusokat (így azok a spektrumból is hiányoznak). Ez számításaink szerint bármilyen kezdőállapotra igaz. Így a diszkrét bázist tekintve a dipólmomentum operátorok komponensinek a szimmetria tulajdonságai és a forgóhullámú közelítés érvényessége vezet oda, hogy az (1) egyenletben részletezett két típusú gerjesztés kvalitatívan különböző felharmonikus spektrumhoz vezet. Ennek az eredménynek az alátámasztása részben numerikus számításokon alapul, jelenleg folyó kutatásaink arra irányulnak, hogy a szimmetrián alapuló effektusok analitikus részleteit felderítsük.

\section{4. Összefoglalás}

A fentiekben azt a kérdést jártuk körül, hogy az atomokon történő magasfelharmonikus-keltés polarizációfüggése hogyan jelenik meg egy olyan modellben, ahol a dinamikát nem közvetlenül a valós térben írjuk le. Diszkrét, de a szórt állapotokat is tartalmazó bázist alkalmazva megmutattuk, 
hogy a jelenség létrejöttében kulcsszerepet játszanak a dipólmomentum mátrixelemek fázisai. Tágabb értelemben ezen mátrixelemek térbeli, és a gerjesztő impulzus időbeli szimmetriájának az együttese határozza meg a felharmonikus komponensek megjelenését.

\section{Köszönetnyilvánítás}

A projekt az Európai Unió támogatásával, az Európai Szociális Alap társfinanszírozásával valósul meg. EFOP-3.6.2-16-2017-00005-Ultragyors fizikai folyamatok atomokban, molekulákban, nanoszerkezetekben és biológiai rendszerekben.

Munkánkat támogatták továbbá TUDFO/47138-1/2019-ITM FIKP és a GINOP-2.3.2-

15-2016-00036 számú pályázatok. Magát az ELI-ALPS projektet (GINOP-2.3.6-15-2015-00001) az Európai Unió és az Európai Regionális Fejlesztési Alap támogatja.

\section{Irodalom}

[1] A. McPherson, G. Gibson, H. Jara, U. Johann, T. S. Luk, I. A. McIntyre, K. Boyer, and C. K. Rhodes, J. Opt. Soc. Am. B 4, 595 (1987).

https://doi.org/10.1364/JOSAB.4.000595

[2] M. Ferray, A. L'Huillier, X. F. Li, L. A. Lompre, G. Mainfray, and C. Manus, J. Phys. B: At. Mol. Phys. 21, L31 (1988).

https://doi.org/10.1088/0953-4075/21/3/001

[3] P. B. Corkum, Phys. Rev. Lett. 71, 1994 (1993).

https://doi.org/10.1103/PhysRevLett.71.1994

[4] M. Lewenstein, P. Balcou, M. Y. Ivanov, A. L'Huillier, and P. B. Corkum, Phys. Rev. A 49, 2117 (1994).

https://doi.org/10.1103/PhysRevA.49.2117

[5] G. Sansone Phys. Rev. A 79, 053410 (2009)

https://doi.org/10.1103/PhysRevA.79.053410

[6] H. Ruf, C. Handschin, R. Cireasa, N. Thiré, A. Ferré, S. Petit, D. Descamps, E. Mével, E. Constant, V. Blanchet, B. Fabre, and Y. Mairesse, Phys. Rev. Lett. 110, 083902 (2013).

https://doi.org/10.1103/PhysRevLett.110.083902

[7] B. Bódi, M. Aladi, P. Rácz, I. B. Földes, and P. Dombi, Opt. Express 27, 26721 (2019).

https://doi.org/10.1364/OE.27.026721

[8] O. Goscinski, Advances In Quantum Chemistry, volume 41, (2002)

https://doi.org/10.1016/S0065-3276(02)41046-5

[9] S. Jiang, H. Wei, J. Chen, C. Yu, R. Lu és C. D. Lin, Phys. Rev. A 96053850 (2017).

https://doi.org/10.1103/PhysRevA.96.053850

[10] P. Meystre, M. Sargent III, Elements of Quantum Optics (Springer, 2007.)

https://doi.org/10.1007/978-3-540-74211-1 